\title{
GEOECONOMICS OF CONSTRUCTION: DIRECTIONS OF DEVELOPMENT OF THE EDUCATIONAL PROGRAM OF PREPARATION OF MASTERS ${ }^{1}$
}

\section{ГЕОЕКОНОМІКА БУДІВНИЦТВА: НАПРЯМИ РОЗРОБКИ ОСВІТНЬОї ПРОГРАМИ ПІДГОТОВКИ МАГІСТРІВ}

UDC 334.021:658:69.009

https://doi.org/10.32843/infrastruct44-11

\section{Wen Mingming}

Candidate of Economic Sciences,

Associate Professor

School of Management,

Guangdong Ocean University, China

Velychko Volodymyr

Candidate of Economic Sciences,

Assistant Lecturer at Department

of Entrepreneurship and Business

Administration

O.M. Beketov National University

of Urban Economy in Kharkiv

Grytskov Evgen

Candidate of Economic Sciences, Associate Professor at Department of Entrepreneurship and Business Administration

O.M. Beketov National University

of Urban Economy in Kharkiv
It is established that the construction sector is important for the territorial development of coastal regions, which ensures the functioning of other sectors and affect the level of life of the population. The decision making system to form a system of knowledge, combining economy of construction enterprises and directions of application of geoinformation systems and technologies, are defined and proposed. The concept of geoeconomics of construction. The proposed stages of application of geoinformation systems and technologies to characterize the economic indicators of construction enterprises. The algorithm of formation and application of the geodatabase of the system of economic indicators of functioning and development of the construction sector and construction companies. It is established that an educational program of training of masters in geoeconomics construction combines specialty geographic information systems and construction economics, allows to prepare professionals for the development of the construction sector.

Key words: geoeconomics of construction, geographic information systems, construction economics, educational masters programs.

Установлено, что строительный сектор является важным для территориального развития приморских регионов, который обеспечивает фрункционирование других сорер и влияет на уровень жизнедеятельности населения. Определено, что в системе принятия решений предложено сорормировать систему знаний, объединяющая экономику строительных предприятий и направления применения геоинорормационных систем и технологий. Обосновано понятие геоэкономики строительства. Предложены этапы применения геоинформационных систем и технологий для характеристики экономических показателей ффункционирования строительных предприятий. Разработан алгоритм формирования и применения баз геоданных системы экономических показателей функционирования и развития строительного сектора и строительных предприятий. Установлено, что образовательная программа подготовки магистров по геоэкономики строительства объединяет специальность геоинформационные системы и экономику строительства, позволяет подготовить специалистов для развития строительного сектора

Ключевые слова: геоэкономика строительства, геоинформационные системы, экономика строительства, образовательная программа подготовки магистров.

Встановлено, що будівельний сектор є важливим для територіального розвитку приморських регіонів, який забезпечує фрункціонування інших сорер та впливає на рівень життєдіяльності населення. Визначено, що у системі прийняття рішень запропоновано сфрормувати систему знань, що об'єднує економіку будівельних підприємств та напрями застосування геоінформаційних систем і технологій. У цьому контексті виникає необхідність розробки освітньої програми щодо підготовки магістрів з геоекономіки будівництва. Метою дослідження є визначення напрямів розробки та реалізації освітньої магістерської програми з геоекономіки будівництва. У рамках дослідження вирішені наступні завдання: формування та обірунтування елементів освітньої магістерської програми з геоекономіки будівництва; визначення практичних аспектів реалізації освітньої магістерської програми з геоекономіки будівництва. Обірунтоване поняття геоекономіки будівництва, яке представляє собою систему економічних відносин стейкхолдерів на державному, регіональному, місцевому рівнях та рівні суб'єктів господарювання у будівельному секторі, що формуються на основі економічних показників, методів і моделей з використанням геоінформаційних систем і технологій, що дозволяє перманентно відстежувати зміни в економічній системі, прогнозувати і приймати обгрунтовані управлінські рішення, з огляду на просторові характеристики на будівельних підприємствах. Запропоновані етапи застосування геоінформаційних систем і технологій для характеристики економічних показників фрункціонування будівельних підприємств. Розроблено алгоритм формування та застосування баз геоданих системи економічних показників функціонування та розвитку будівельного сектору й будівельних підприємств. Встановлено, що освітня програма підготовки магістрів з геоекономіки будівниитва об'єднує напрям підготовки геоінсрормаційні системи та економіку будівництва, що дозволяє підготовити спеціалістів для розвитку будівельного сектору, будівельних підприємств, враховуючи напрями та особливості застосування сучасного геоінформаційного інструментарію, просторового забезпечення для зростання ефективності прийняття управлінських рішень.

Ключові слова: геоекономіка будівництва, геоінформаційні системи, економіка будівництва, освітня програма підготовки магістрів.

Problem Statement. The construction sector is important for the territorial development of coastal regions. It ensures the functioning of other areas and affects the living standards of the population. Current trends in the development of the construction sector indicate a slowdown in key performance indicators. This negatively affects the development of regions and the state and indicates the need to change the trajectory of the construction sector through the use of geographic information systems and technologies to form a quantitative

${ }^{1}$ This article (monograph) is supported by the project of Enhancing School With Innovation of Guangdong Ocean University's (230420023) and by the program for scientific research start-up funds of Guangdong Ocean University and spatial basis for management decisions. In addition, of particular importance is the formation and use of economic decisions, the definition of relevant indicators. In the decision-making system, it is proposed to form a system of knowledge that combines the economy of construction companies and the application of geographic information systems and technologies. In this context, there is a need to develop an educational program for the preparation of masters in geoeconomics of construction. Thus, the research topic is relevant and timely.

Literature Review. The scientists V. Velychko [1;2], E. Hrytskov [1; 2; 4], O. Kvasnitska [3], K. Mamonov [4; 10], T. Momot [5], S. Pokropivnyi [6], T. Pushkar [7] and others. 
Directions and features of the use of geographic information systems and technologies are presented in the developments [8-13].

Along with this, the issues of defining and applying the geoeconomics of construction based on the development of the modern educational system remain unresolved.

Materials and methods. The study uses general scientific (systematization, comparison, dialectical development of systems, methodologies of legal and information and analytical support of construction geoeconomics) and special (analytical, methods of expert analysis, geoinformation analysis, mathematical modeling) methods.

Research Objective. The purpose of the study is to determine the directions of development and implementation of an educational master's program in geoeconomics of construction.

The study solves the following tasks: formation and substantiation of elements of the educational master's program in geoeconomics of construction; determination of practical aspects of realization of the educational master's program on geoeconomics of construction.

Key Results. Summarizing the existing theoretical and methodological issues in the proposed definition of geoeconomics construction, which is a system of economic relations of stakeholders at the state, regional, local levels and the level of business entities in the construction sector, which are based on economic indicators, methods and models using geographic information systems and technologies, allowing to permanently monitor changes in the economic system, to predict and make informed management decisions, taking into account the spatial characteristics of construction enterprises.

For the implementation of geoeconomics, the construction of the applied GIS tools that includes a set of interrelated stages is proposed:

1. The formation of information and analytical support in relation to the status and functioning of the construction sector in general and construction enterprises in particular.

2. The creation of a spatial support for the construction companies, given the peculiarities of their functioning.

3. Application of geoinformation systems and technologies to characterize the economic indicators of construction enterprises.

4. Construction of the geoinformational maps of economic indicators of construction enterprises.

5. Monitoring of changes in economic indicators of construction enterprises.

6. Interpretation of the results.

The formation of information and analytical support in relation to the status and functioning of the construction sector is based on the relevant indicators:

- index of volume of production and sales of construction products;
- index of capital investment;

- total area of residential buildings.

Development of information-analytical support in relation to the status and functioning of construction companies is carried out by applying the indicators of their financial status, level of formation and use of fixed and current assets, sources of financing, the development index is an integral indicator of the formation and use of corporate social responsibility, the level of stakeholders in relations and others.

Formation of the spatial support of construction companies is carried out using the existing cartographic support, given the characteristics of functioning of business entities in construction.

Application of geoinformation systems and technologies to characterize the economic indicators of construction enterprises includes the following steps:

- the formation of instrumental support use of geographic information systems and technologies in the software package ArcGIS;

- the use of software modules ArcCatalog (development and working with a geodatabase of economic indicators of functioning and development of the construction sector and construction companies); ArcMap (display of vector data set of the evaluation indicators of functioning and development of the construction sector and construction companies); ArcScene (development and modeling presentation layers of the system of economic indicators of functioning and development of the construction sector and construction companies);

- development of algorithm of formation and application of the geodatabase of the system of economic indicators of functioning and development of the construction industry and construction enterprises (Figure 1).

In accordance with the developed algorithm of formation and application of geodatabases, it is determined that at the first stage data are formed and applied on the basis of information and analytical support of indicators on the functioning and development of the construction sector and construction companies. At the next stage, the formation of geodata economic indicators is carried out, taking into account the spatial features of the functioning and development of the construction sector and construction companies using the procedural block ArcCatalog.

If the conditions correspond to the procedures of a certain block ArcCatalog (Yes), then geodatabases are formed in GIS tooling and systematization of economic indicators of functioning and development of the construction sector and construction companies, development of shapefile basis for geoinformation modeling, linking economic indicators by regions and construction companies, formation of spatial information on economic indicators of functioning of construction sector and construction enterprises. If (No), the improvement and replenishment of the geodatabase 


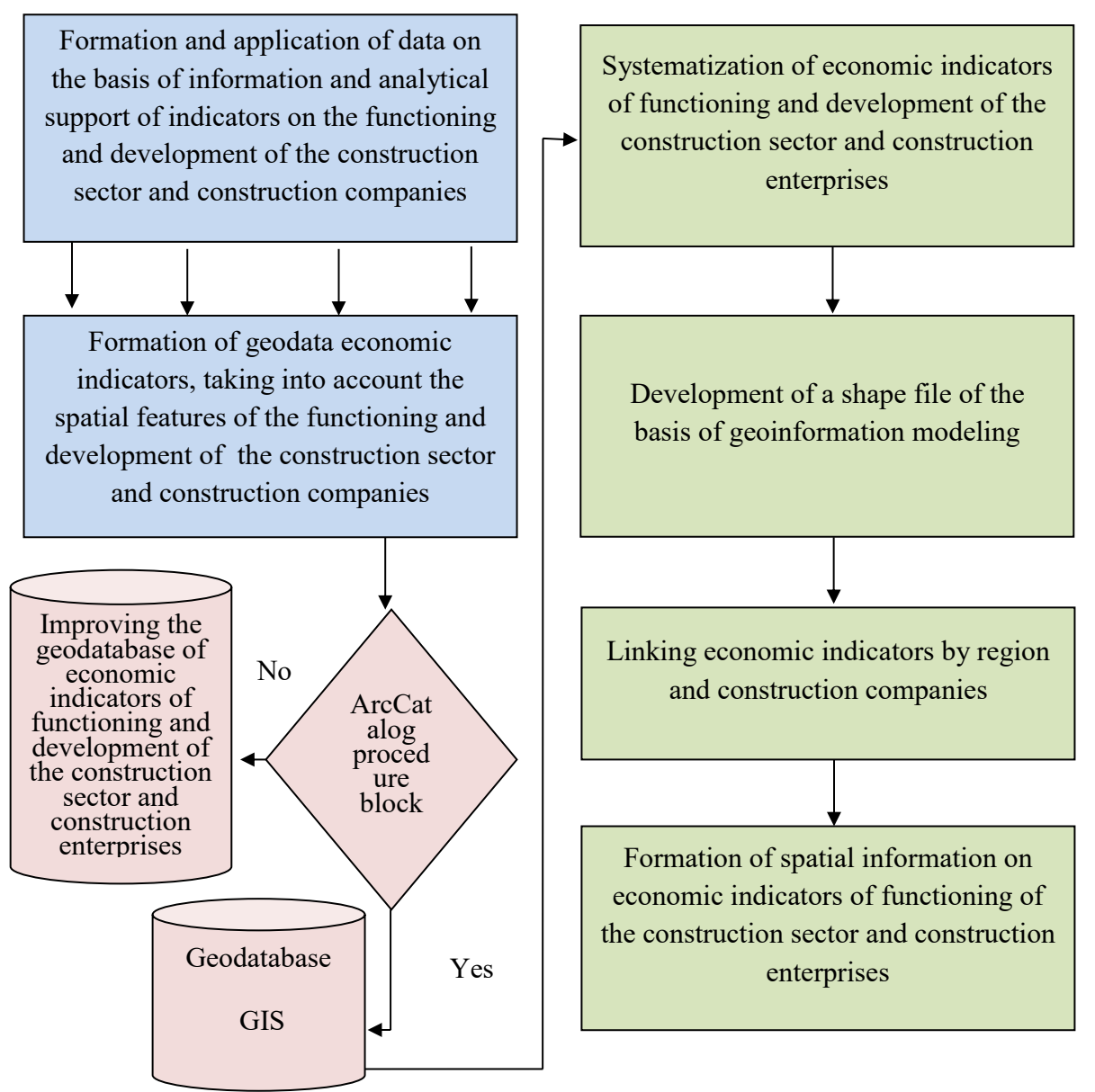

Figure 1. Algorithm of formation and application of geodatabases of the system of economic indicators of functioning and development of the construction sector and construction enterprises

of economic indicators of functioning and development of the construction sector and construction enterprises is carried out.

To implement the direction of geoeconomics of construction, there is a need to train masters in the new direction. This master's degree program combines geographic information systems and construction economics, which allows to train specialists for the development of the construction sector, construction companies, taking into account the areas and features of modern geographic information tools, spatial support to increase management decision-making.

In the framework of the presented master's program, the goals and objectives of the geoeconomics of construction are highlighted. The main objectives of the study the geoeconomics are:

- obtaining additional specific theoretical knowledge and skills, their use, the development of special computational and graphical complexes of geographic information systems used in the economy of the construction sector and construction enterprises;

- collecting raw materials for later use in course design, implementation and master's scientific works;
- study of project documentation, acquisition of reading skills of working drawings and obtaining the necessary practical knowledge on engineering, in the course of the works, master of design and further engineering work in the specialty;

- familiarization with the principles of design and estimate documentation;

- familiarization with the methods of preparation of materials for testing;

- familiarization with advanced methods of labor, mechanization, new efficient materials, products and structures;

- identification of areas and features of the economy of the construction sector and construction enterprises;

- formation of information and analytical support for assessing the efficiency and effectiveness of construction economics;

- formation of spatial protection on the basis of application of geoinformation systems;

- spatial modeling of economic facilities construction;

- formation of multilevel system of indicators applied in construction economics; 
- economic and mathematical modeling of economic indicators of construction;

- formation of mechanisms of functioning and development of the economy of construction.

The main tasks are:

- application of theoretical knowledge obtained at the university directly in practical work, consolidation and expansion of knowledge in the field of calculation and design, technology, organization, management and economics of construction;

- practical use of elements of geoinformation complexes in the implementation of course projects and master's theses;

- participation in the preparation of geoinformation support for decision-making in the field of construction economics;

- application of the results of geoinformation modeling to ensure the growth of economic indicators;

- formation of a system of monitoring geoinformation maps for making sound management decisions at the objects of the construction economy.

In the process of studying the master's program in geoeconomics of construction there are used: methods and models of economic and mathematical modeling, quantitative and qualitative methods, forecasting, geoinformation analysis and modeling, systematization and generalization.

Within the framework of the master's program there are used: specialized software in the construction sector in the development of design estimates, geographic information systems, information systems for determining the indicators of construction economics, economic and mathematical modeling and forecasting, neural networks.

The modules of the educational master's program in geoeconomics of construction are offered:

1. The main directions and principles of formation and use of geographic information systems.

2. Features of formation and use of geographic information systems on objects of construction economy.

3. Theoretical and methodological provisions for determining the economics of construction.

4. Formation of a system of indicators used in the field of construction economics.

5. Economic and mathematical modeling of indicators used in the field of construction economics.

6. Directions and features of construction of geoinformation monitoring maps of indicators of construction economy.

7. Development and implementation of tools to ensure the development of the construction economy on the basis of existing geoinformation support.

As a result of the implementation of the educational master's program, a student-oriented, competencybased approach is implemented, which allows to train modern specialists in the field of construction geoeconomics to ensure the development of the construction sector and construction companies. An example of the implementation of the educational master's program is the developed monitoring geoinformation

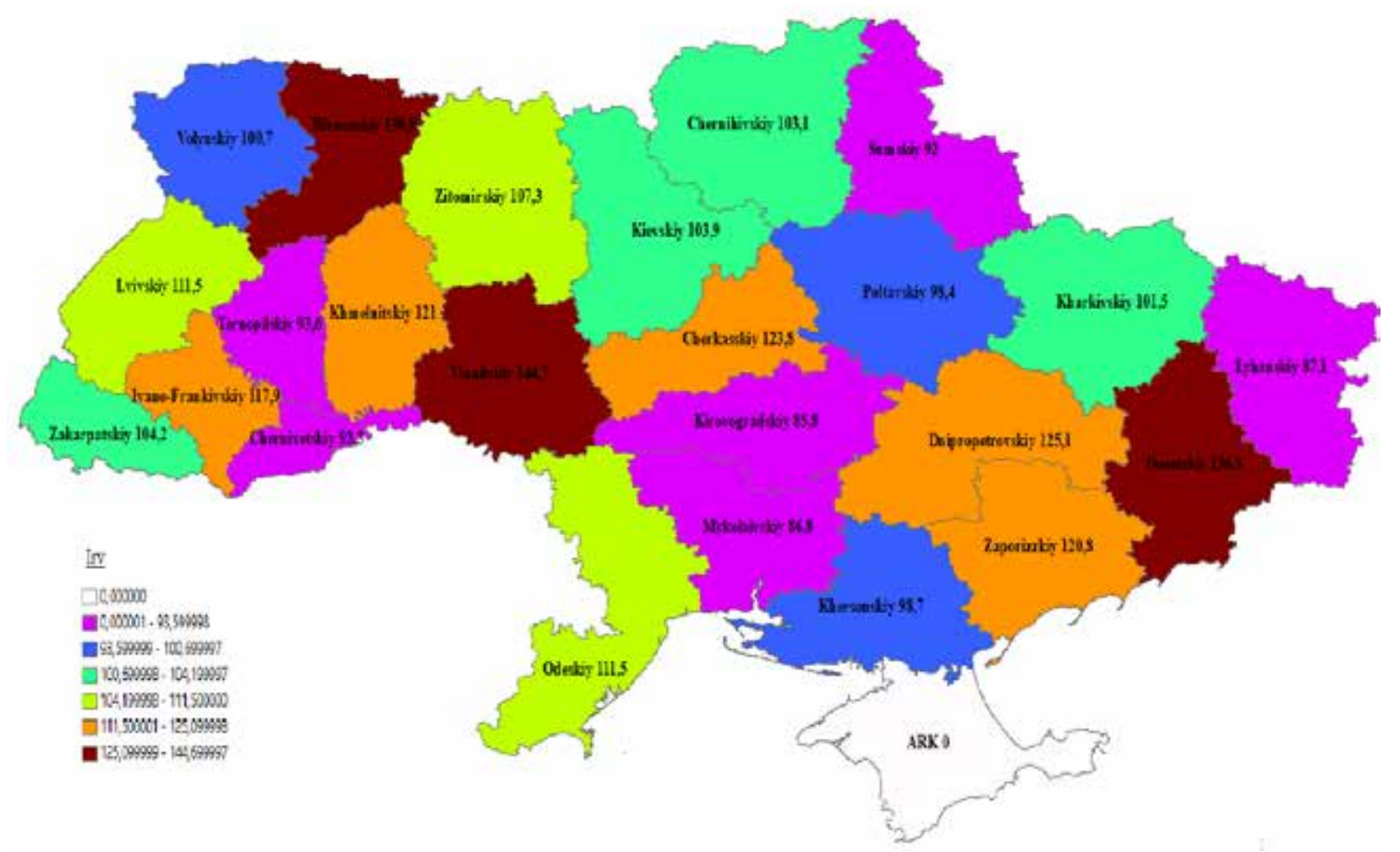

Figure 2. Geoinformation monitoring map of the index of production and sales of construction products by region, $\%$ 


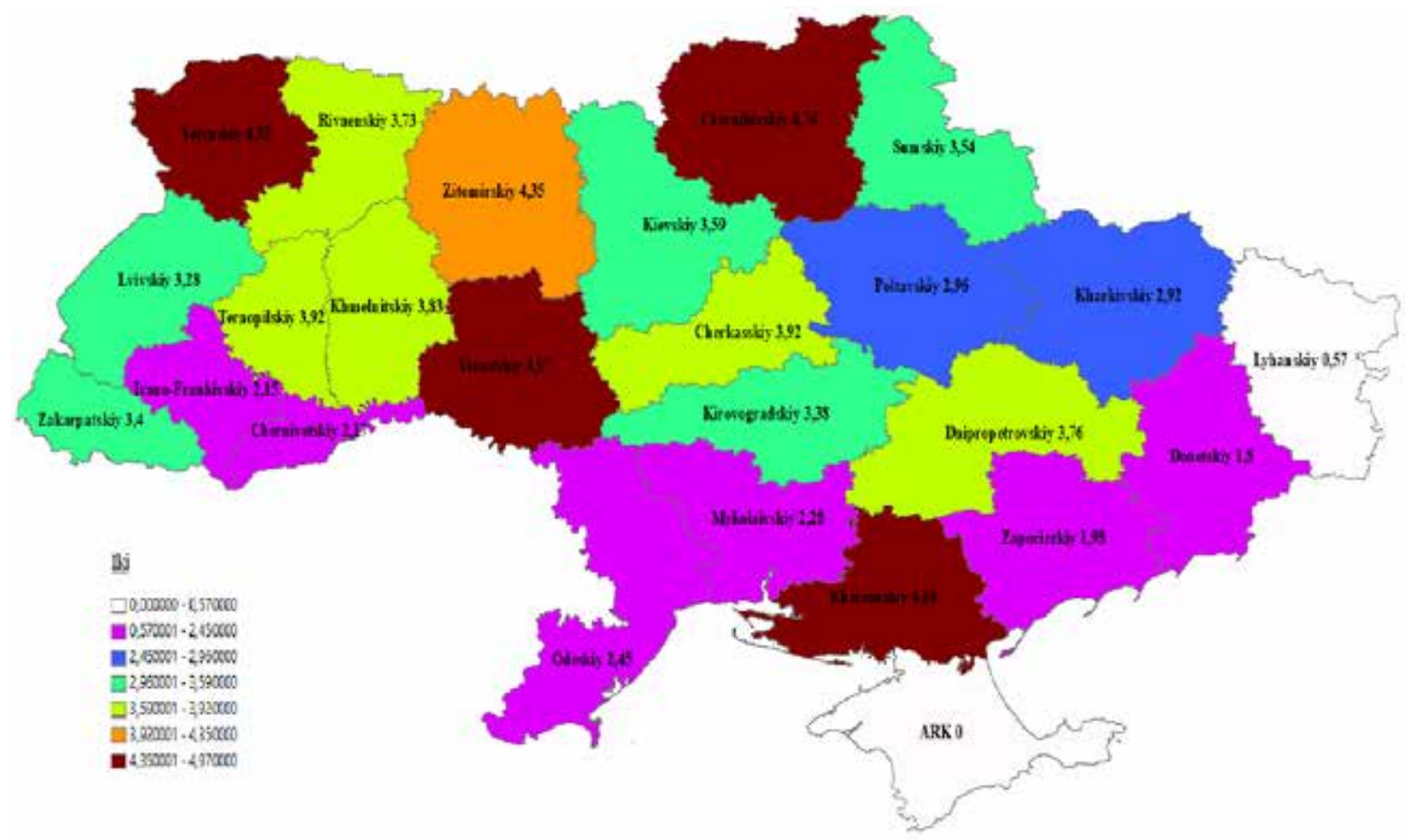

Figure 3. Geoinformation monitoring map of the capital investment index by region, rel. from

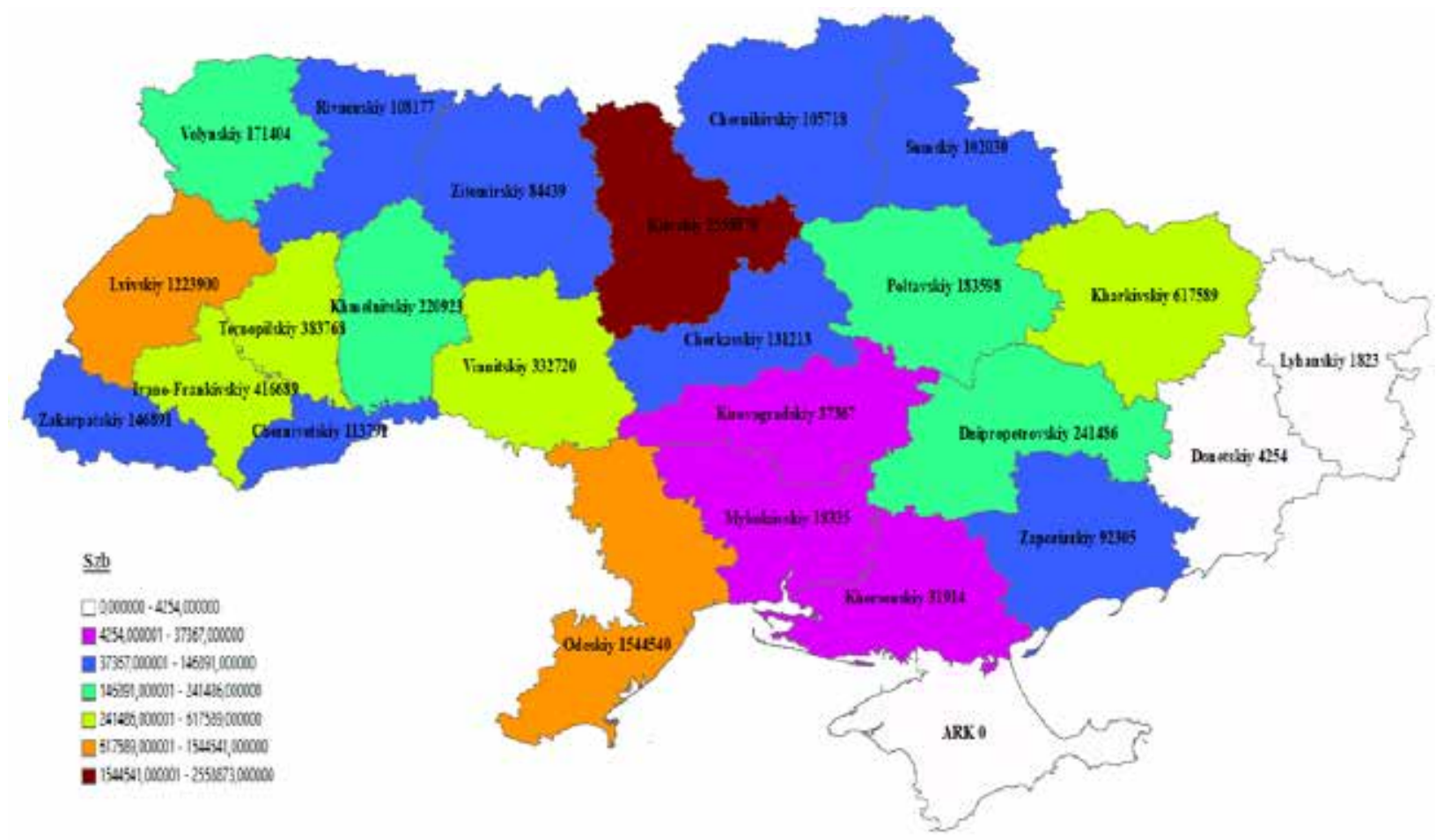

Figure 4. Geoinformation monitoring map of the total area of residential buildings by region, $\mathrm{m}^{2}$

maps of the functioning of the construction sector and construction enterprises (Figures 2-4):

Conclusions. Thus, a "new" educational master's program in geoeconomics of construction has been developed, which allows to form modern approaches for the implementation of directions of construction development, scientific provisions. This creates a basis for making sound management decisions, taking into account geoinformation and economic aspects of the construction sector. The proposed educational master's program forms a "new" educational and theoretical and methodological direction of development of modern scientific thought. 


\section{REFERENCES:}

1. Velychko V., Grytskov E., Zubarev D. (2020) Stakeholders of construction enterprises: areas and features of interaction. Naukovyi ekonomichnyi zhurnal «Intelekt XXI». Vydavnychyi dim «Helvetyka», № 1. pp. 108-113.

2. Hrytskov E., Velychko V., Zubarev D. (2019) Sotsialna korporatyvna vidpovidalnist u systemi vzaiemodii zi steikkholderamy budivelnykh pidpryiemstv [Social corporate responsibility in the system of interaction with stakeholders of construction companies]. Pidpryiemnytstvo ta innovatsii, № 9. pp. 70-76.

3. Kvasnitska O. O. (2011) Sutnist budivelnoi diialnosti: teoretychnyi pohliad [The essence of construction: a theoretical view]. Naukovi pratsi Natsionalnoho universytetu «Odeska yurydychna akademiia». T. 10. pp. 413-423.

4. Mamonov K. A., Prunenko D. O., Hrytskov E. V. (2014) Vyznachennia intelektualnoho kapitalu budivelnykh pidpryiemstv: pidkhody ta osoblyvosti zastosuvannia [Definition of intellectual capital of construction enterprises: approaches and features of application]. Biznes-Inform, № 8. pp. 313-316.

5. Momot T. V., Tararuiev Yu. O. (2006) Zastosuvannia metodu nadlyshkovykh prybutkiv $v$ protsesi otsinky intelektualnykh aktyviv budivelnykh pidpryiemstv [Application of the method of excess profits in the process of assessing the intellectual assets of construction companies]. Kultura narodov Prychernomoria, № 83. pp. 16-18.

6. Pokropyvnoho S. F. (2001) Ekonomika pidpryiemstva [Business economics]. Kyiv: KNEU. (in Ukrainian)

7. Pushkar T. A. (2013) Osoblyvosti ekonomichnoi bezpeky pidpryiemstv budivelnoi haluzi [Features of economic security of enterprises of the construction industry].Problemy i perspektyvy rozvytku pidpryiemnytstva, № 2(5). pp. 134-139.

8. Hensetskyi M. P. (2004) Metodychni osnovy heoinformatsiinoho zabezpechennia inzhenernykh komunikatsii v ekspluatatsiinykh systemakh [Methodical bases of geoinformation support of engineering communications in operational systems]: (PhD Thesis). Kyiv.

9. Korniiets A. V. (2015) Osoblyvosti zastosuvannia HIS-tekhnolohii v Ukraini [Features of GIS technologies application in Ukraine]. Kharkiv. pp. 47-50.

10. Mamonov K. A., Shterndok E. S. (2017) Metody i modeli otsinky formuvannia, rozpodilu ta vykorystannia zemel mehapolisu, shcho zastosovuiutsia u systemi heoinformatsiinoho zabezpechennia [Methods and models for assessing the formation, distribution and use of land in the metropolis used in the system of geographic information support]. Dnipro: Porohy. pp. 92-96.

11. Paleha Yu. N., Oleshenko A. V., Solomaha I. V. (2012) Primenenie GIS-tehnologii v gradostroitelnyh proektah na gosudarstvennom i regionalnom urovnyah [The use of GIS technologies in urban projects at the state and regional levels]. Uchenye zapiski Tavricheskogo nacionalnogo universiteta im. V. I. Vernadskogo. Geografiya. 25 (64). № 1. pp. 155-166.

12. Shterndok E. S. (2017) Modeliuvannia vplyvu prostorovykh faktoriv na otsinku ta vykorystannia zemel mehapolisu [Modeling the influence of spatial factors on the assessment and use of land in the metropolis]: (PhD Thesis). Kharkiv.
13. Shypulin V. D. (2014) Osnovy GIS-analizu [Fundamentals of GIS analysis]. Kharkiv: KhNUMH im. O. M. Beketova. (in Ukrainian)

\section{БІБЛІОГРАФІЧНИЙ СПИСОК:}

1. Velychko V., Grytskov E., Zubarev D. Stakeholders of construction enterprises: areas and features of interaction / Науковий економічний журнал «Інтелект XXI». Видавничий дім «Гельветика», 2020. № 1. С. 108-113.

2. Грицьков Є., Величко В., Зубарєв Д. Соціальна корпоративна відповідальність у системі взаємодії зі стейкхолдерами будівельних підприємств / Підприємництво та інновації, 2019. № 9. С. 70-76.

3. Квасніцька О. О. Сутність будівельної діяльності: теоретичний погляд / Наукові праці Національного університету «Одеська юридична академія». 2011. Т. 10. С. 413-423.

4. Мамонов К. А., Пруненко Д. О., Грицьков Є. В. Визначення інтелектуального капіталу будівельних підприємств: підходи та особливості застосування / Бізнес-Інфрорм, 2014. № 8. С. 313-316.

5. Момот Т. В., Тараруєв Ю. О. Застосування методу надлишкових прибутків в процесі оцінки інтелектуальних активів будівельних підприємств / Культура народов Причерноморья. 2006. № 83. С. 16-18.

6. Економіка підприємства : підручник / за ред. С. Ф. Покропивного. К. : КНЕУ, 2001. 457 с.

7. Пушкар Т. А. Особливості економічної безпеки підприємств будівельної галузі / Проблеми і перспективи розвитку підприємництва. 2013. № 2(5). С. 134-139.

8. Генсецький М. П. Методичні основи геоіндрормаційного забезпечення інженерних комунікацій в експлуатаційних системах: дис. ...канд. техн. наук: 05.24.01 / Київ: КНУБА, 2004. URL: http://disser.com.ua/ content/20248.html.

9. Корнієць А. В. Особливості застосування ГІСтехнологій в Україні / матеріали науково-практичної конференції, присвяченої міжнародному дню геоінформаційних систем. (Харків, 19 листопада 2015 р.) ХНУМГ ім. О. М. Бекетова, 2015. С. 47-50.

10. Мамонов К. А., Штерндок Е. С. Методи і моделі оцінки фрормування, розподілу та використання земель мегаполісу, що застосовуються у системі геоінформаційного забезпечення / Економічна кібернетика: аспекти становлення і розвитку електронної економіки: матеріали всеукр. наук.-практ. конфр. (Дніпро, 1-2 берез 2017 р.) Дніпро: Пороги, 2017. С. 92-96.

11. Палеха Ю. Н., Олещенко А. В., Соломаха И. В. Применение ГИС-технологий в градостроительных проектах на государственном и региональном уровнях / Ученые записки Таврического национального университета им. В. И. Вернадского. Геограсрия. 2012. 25 (64). № 1. С. 155-166.

12. Штерндок Е. С. Моделювання впливу просторових фракторів на оцінку та використання земель мегаполісу: дис...канд. техн. наук: 05.24.04. ХНУМГ імені О. М. Бекетова, 2017. 246 с.

13. Шипулін В. Д. Основи ГІС-аналізу: навч. посіб. ХНУМГ ім. О. М. Бекетова. 2014. 336 с. 